\title{
Fatty Acids in Heterocyclic Synthesis. Part XVII: Synthesis of Non Ionic Surfactants Containing Piperidine, Piperazine, Imidazole Based on Thiadiazole and Microbiological Activities Evaluation
}

\author{
Abdelmotaal Abdelmajeid, Mahasen Saad Amine, Reda Ali Hassan \\ Department of Chemistry, Faculty of Science, Benha University, Benha, Egypt \\ Email: reda.ali201080@yahoo.com
}

How to cite this paper: Abdelmajeid, A., Amine, M.S. and Hassan, R.A. (2017) Fatty Acids in Heterocyclic Synthesis. Part XVII: Synthesis of Non Ionic Surfactants Containing Piperidine, Piperazine, Imidazole Based on Thiadiazole and Evaluation of the Microbiological Activities. International Journal of Organic Chemistry, 7, 346-368. https://doi.org/10.4236/ijoc.2017.74029

Received: June 3, 2017

Accepted: December 12, 2017

Published: December 15, 2017

Copyright $\odot 2017$ by authors and Scientific Research Publishing Inc. This work is licensed under the Creative Commons Attribution International License (CC BY 4.0).

http://creativecommons.org/licenses/by/4.0/

\begin{abstract}
A series of novel scaffolds Thiadiazolyl Piperidine, Thiadiazolyl Piperazine, thiadiazolidine, Thiadiazolyl thiazole and Thiadiazolyl-imidazole-Thione were synthesized from cheap, available and biologically active stearic acid. 2-amino-5-heptadecyl 1,3,4-thiadiazole reacts with chloroacetyl chloride and produced 2-choloro-N-(5-heptadecyl-1,3,4-Thiadiazole-2-yl) acetamide. Which allowed to react with Piperidine, Piperazine, urea and/or Thiourea and Potassium thiocyanate, and the latest scaffolds have been synthesized, respectively, and the structures of these compounds were established by elemental analysis, MS, IR and ${ }^{1} \mathrm{H}$-NMR spectral data. The antimicrobial activities of the synthesized compounds were evaluated in-vitro against strains of gram +ve, gram -ve bacteria and fungi. Nonionic surfactant were obtained by addition of different moles of propylene oxide (3,5,7 mole) to the synthesized compounds bearing an active hydrogen. Physico-chemical and surface properties as well as biodegradability of the synthesized non-ionic surfactants were evaluated.
\end{abstract}

\section{Keywords}

2-Aminothiadiazole, Imidazole, Thiazole, Stearic Acid, Thiazolidine, Propylene Oxide, Nonionic Surfactant, Antimicrobial Activity

\section{Introduction}

1,3,4-Thiadiazole and its derivatives continue to be of great interest owing to their great pharmaceutical and industrial importance. The specific pharmaco- 
logical activities include antioxidant [1], anticancer [2] [3], anti-inflammatory [4] [5], antimicrobial [6] [7], anti-HIV [8] [9], antiviral [10], anticonvulsant [11] [12]. Addition of the long alkyl chain (hydrophobic part) and propylene oxide (lipophilic part), to the Thiadiazole nucleus increases its solubility in water and enhances the potential of their usage as nonionic surfactants. Surfactants are one of the most important and widely used products in industry. This prompted us to continue our research program about the utilization of fatty acids in heterocyclic synthesis, to synthesize novel nonionic surfactants [13]-[19]. Herein, we report the synthesis and some reactions of 2-chloro-N-(5-heptadecyl-1,3,5 Thiadiazole-2-yl) acetamide (2) with piperidine, piperazine, urea, Thiourea and Potassium thiocyanate then propylene oxide was added in quantitative amounts to produce new types from Nonionic surfactants.

\section{Experimental Protocols}

\subsection{Materials}

Stearic acid, Urea, Thiourea, Acetone, Benzaldehyde, Benzene, Ethanol, Anhydrous potassium carbonate, Anhydrous sodium acetate (Adwic 99\%), Phosphorus oxy chloride (Alphachemie, 98\%), Choloro acetyl chloride (Loba chemie, 98\%), Thiosemicarbazide (Oxford lab chem., 98\%), Triethyl amine(Loba chemie, 98\%), Potassium thiocyanate (Loba chemie, 98\%), Pipridine (SdFine-chem. limited, 99\%), Piperazine (Loba chemie, 98\%), Glacial acetic acid (SdFine-chem. limited, 99\%).

\subsection{Structures Elucidation}

The new compounds structure confirmation is established via elemental analysis detected by using automatic CHNS apparatus as well as different spectroscopic tools (MS, IR, ${ }^{1} \mathrm{H}-\mathrm{NMR}$ spectra). All melting points are determined by the open capillary method and are uncorrected. All mass spectra of the synthesized compounds were recorded on a Shimadzu GCMS-QP-1000EXmass spectrophotometer, IR spectra ( $\mathrm{KBr}$ disk) of the new compounds were checked on JASCO FT/IR-4100 (Japan). ${ }^{1} \mathrm{H}-\mathrm{NMR}$ spectra were recorded in Varian Mercury VXR-300 spectrometer using TMS as internal reference. The surface active properties were carried out at the Chemistry Department, Faculty of Science, Benha University, Egypt. Antibacterial and antifungal activities were carried out in the Micro Analytical Center, Faculty of Science, Azhar University, Egypt.

\subsection{Synthesis of 5-Heptadecyl-1,3,4-Thiadiazole-2-Amine (1)}

A solution of stearic acid $(0.01 \mathrm{~mol})$ and Thiosemicarbazide $(0.01 \mathrm{~mol})$ in $(20$ $\mathrm{mL}$ ) POCl3 was heated for $6 \mathrm{~h}$. The reaction mixture was concentrated, cooled, and then poured onto crushed ice while stirring. The produced solid was filtered off and recrystallized from ethanol. Compound 1 was obtained as a yellow powder in $75 \%$ yield, $\mathrm{mp} 108^{\circ} \mathrm{C}-110^{\circ} \mathrm{C}$, IR (KBR): v3376, $3267\left(\mathrm{NH}_{2}\right), 2919$ 
$\left(\mathrm{CH}_{\text {aliphatic }}\right), 1686,1663(\mathrm{C}=\mathrm{N}) \mathrm{cm}^{-1} \cdot 1 \mathrm{H}-\mathrm{NMR}$ (DMSO-d6): $\delta 6.92(\mathrm{~s}, 2 \mathrm{H}, \mathrm{D} 2 \mathrm{o}$ exchangeable, $\left.\mathrm{NH}_{2}\right), \delta 1.24\left(\mathrm{~m}, 32 \mathrm{H}, 16 \mathrm{CH}_{2}\right), \delta 0.88\left(\mathrm{t}, 3 \mathrm{H}, \mathrm{CH}_{3}\right) . \mathrm{MS} \mathrm{m} / \mathrm{z}(\%)$ : $340(\dot{\mathrm{M}}++1,1.81) 339(\dot{\mathrm{M}}+, 1.8), 239$ (0.67), 115 (100), 100 (0.15), 76 (0.9).

Anal. Calc. (\%) for $\mathrm{C}_{19} \mathrm{H}_{37} \mathrm{~N}_{3} \mathrm{~S}: \mathrm{C}, 67.20, \mathrm{H}, 10.89, \mathrm{~N}, 12.37$. Found: C, 67.31, H, $10.95, \mathrm{~N}, 12.50$.

\subsection{Synthesis of 2-Chloro-N-(5-Heptadecyl-1,3,5 Thiadiazole-2-yl) Acetamide (2)}

Equimolar quantities of compound 1 and chloroacetylcholoride in dry benzene $(30 \mathrm{~mL})$ in the presence of Triethyl amine $(0.1 \mathrm{~mL})$ was boiled for $7 \mathrm{~h}$. The reaction mixture was concentrated, cooled. The obtained solid product was filtered off, dried and recrystallized from ethanol. Compound 2 was obtained as a pale yellow powder in $80 \%$ yield, $\mathrm{mp} 120^{\circ} \mathrm{C}-122^{\circ} \mathrm{C}$.

IR (KBR): v3374, (NH), $2850\left(\mathrm{CH}_{\text {aliphatic }}\right), 1681(\mathrm{C}=\mathrm{O}), 1658(\mathrm{C}=\mathrm{N}) \mathrm{cm}^{-1}$. 1H-NMR (DMSO-d6): $\delta 6.9$ (s, H, D2o exchangeable, NH), $\delta 4.27(\mathrm{~s}, 2 \mathrm{H}$, $\left.\mathrm{CH}_{2} \mathrm{Cl}\right), \delta 1.24\left(\mathrm{~m}, 32 \mathrm{H}, 16 \mathrm{CH}_{2}\right), \delta 0.88\left(\mathrm{t}, 3 \mathrm{H}, \mathrm{CH}_{3}\right)$.

MS m/z (\%): $417(\dot{\mathrm{M}}++2,11.8), 415(\dot{\mathrm{M}}+, 14.3), 339$ (0.67), 324 (0.48), 239 (0.34), 115 (100), 93 (0.74).

Anal. Calc. (\%) for $\mathrm{C}_{21} \mathrm{H}_{38} \mathrm{ClN}_{3} \mathrm{OS}$ : C, 60.62, H, 9.21, N, 10.10, Cl, 8.52. Found: C, 60.74, H, 9.10, N, 10.20, Cl, 8.40.

\subsection{Synthesis of N-(5-Heptadecyl-1,3,4-Thiadiazol-2-yl)-2-(Piperidin-1-yl) Acetamide (3)}

A solution of compound $2(0.01 \mathrm{~mol})$ and Piperidine $(0.01 \mathrm{~mol})$ in ethanol $(30$ $\mathrm{ml})$ in the presence of anhydrous Potassium carbonate $(0.5 \mathrm{gm})$, was heated for 6 h. The reaction mixture was concentrated, cooled. The solid product obtained was filtered off, dried and recrystallized from ethanol. Compound 3 was obtained as a yellow powder in $82 \%$ yield, $\mathrm{mp} 90^{\circ} \mathrm{C}-92^{\circ} \mathrm{C}$. IR (KBR): v3279, (NH), 2920, $2851\left(\mathrm{CH}_{\text {aliphatic }}\right), 1674(\mathrm{C}=\mathrm{O}), 1665(\mathrm{C}=\mathrm{N}) \mathrm{cm}^{-1}$.

1H-NMR (DMSO-d6): $\delta 6.90$ (s, 1H, D2o exchangeable, NH), $\delta 3.26(\mathrm{~s}, 2 \mathrm{H}$, $\left.\mathrm{CH}_{2}\right), \delta 2.51\left(\mathrm{t}, 4 \mathrm{H}, \mathrm{CH}_{2}-\mathrm{N}-\mathrm{CH}_{2}\right), \delta 1.6\left(\mathrm{t}, 6 \mathrm{H}, 3 \mathrm{CH}_{2}\right), \delta 1.24\left(\mathrm{~m}, 32 \mathrm{H}, 16 \mathrm{CH}_{2}\right), \delta$ $0.88\left(\mathrm{t}, 3 \mathrm{H}, \mathrm{CH}_{3}\right) . \mathrm{MS} \mathrm{m} / \mathrm{z}(\%): 464(\dot{\mathrm{M}}+, 1.21), 380$ (0.18), 338 (2.72), 265 (1.01), 115 (100), 84 (13.71).

Anal. Calc. (\%) for $\mathrm{C}_{26} \mathrm{H}_{48} \mathrm{~N}_{4} \mathrm{SO}$ : C, 67.19, H, 10.41, N, 12.06. Found: C, 67.32, $\mathrm{H}, 10.55, \mathrm{~N}, 12.21$.

\subsection{Synthesis of \\ N-(5-Heptadecyl-1,3,4-Thiadiazol-2-yl)-2-(Piperazin-1-yl) Acetamide (4)}

Equimolar amounts of compound 2 and piperazine in the presence of anhydrous Potassium carbonate $(0.5 \mathrm{gm})$, was heated for $6 \mathrm{~h}$. The reaction mixture was concentrated, cooled. The solid product obtained was filtered off, dried and recrystallized from ethanol. Compound 4 was obtained as a yellow powder in $82 \%$ 
yield, $\mathrm{mp} 86^{\circ} \mathrm{C}-88^{\circ} \mathrm{C}$

IR (KBR): v3281, 3110 (NH's), 2919, 2850 ( $\left.\mathrm{CH}_{\text {aliphatic }}\right), 1680$ (C=O), 1658 $(\mathrm{C}=\mathrm{N}) \mathrm{cm}^{-1} .1 \mathrm{H}-\mathrm{NMR}(\mathrm{DMSO}-\mathrm{d} 6): \delta 10.5,6.85(\mathrm{~s}, 1 \mathrm{H}, \mathrm{NH}), \delta 3.26\left(\mathrm{~s}, 2 \mathrm{H}, \mathrm{CH}_{2}\right)$, $\delta 2.6\left(\mathrm{t}, 4 \mathrm{H}, \mathrm{CH}_{2}-\mathrm{NH}-\mathrm{CH}_{2}\right), \delta 2.3\left(\mathrm{t}, 4 \mathrm{H}, \mathrm{CH}_{2}-\mathrm{N}-\mathrm{CH}_{2}\right), \delta 1.25\left(\mathrm{~m}, 32 \mathrm{H}, 16 \mathrm{CH}_{2}\right)$, $\delta 0.88\left(\mathrm{t}, 3 \mathrm{H}, \mathrm{CH}_{3}\right)$.

MS m/z (\%): $466(\dot{M}++1,0.18), 465(\mathrm{M}+, 0.92), 380$ (0.95), 339 (2.86), 265 (1.56), 115 (100), 85 (16. 18).

Anal. Calc. (\%) for $\mathrm{C}_{25} \mathrm{H}_{47} \mathrm{~N}_{5} \mathrm{OS}$ : C, 64.47, H, 10.17, N, 15.04. Found: C, 64.60, $\mathrm{H}, 10.02, \mathrm{~N}, 15.20$.

\subsection{Synthesis of 3-(5-Heptadecyl-1,3,4 Thiadiazol-2-yl) Imidazolidine-2,4-Dione (5).}

It was obtained from reaction of compound 2 with Urea in ethanol $(30 \mathrm{ml})$ in the presence of anhydrous Potassium carbonate $(0.5 \mathrm{gm})$, and was boiled for 10 h. The reaction mixture was concentrated, cooled. The solid product obtained was filtered off, dried and recrystallized from ethanol. Compound 5 was obtained as a pale yellow powder in $80 \%$ yield, $\mathrm{mp} 96^{\circ} \mathrm{C}-98^{\circ} \mathrm{C}$.

IR (KBR): v3365 (NH), 2920, $2851\left(\mathrm{CH}_{\text {aliphatic }}\right), 1680,1672(\mathrm{C}=\mathrm{O}), 1658(\mathrm{C}=\mathrm{N})$ $\mathrm{cm}^{-1} .1 \mathrm{H}-\mathrm{NMR}$ (DMSO-d6): $\delta 6.96,(\mathrm{~s}, 1 \mathrm{H}, \mathrm{D} 2 \mathrm{o}$ exchangeable, NH), $\delta 5.4(\mathrm{~s}, 2 \mathrm{H}$, $\left.\mathrm{CH}_{2}\right), \delta 1.24\left(\mathrm{~m}, 32 \mathrm{H}, 16 \mathrm{CH}_{2}\right), \delta 0.85\left(\mathrm{t}, 3 \mathrm{H}, \mathrm{CH}_{3}\right)$.

MS m/z (\%):423 (M்++1, 6.56), 324 (6.08), 239 (1.56), 115 (100), 99 (2.86).

Anal. Calc. (\%) for $\mathrm{C}_{22} \mathrm{H}_{38} \mathrm{~N}_{4} \mathrm{O}_{2}$ S: C, 62.52, H, 9.06, N, 13.26. Found: C, 62.66, $\mathrm{H}, 8.95, \mathrm{~N}, 13.02$.

\subsection{Synthesis of (Z)-5-Benzylidene-3-(5-Heptadecyl-1,3,4 Thiadiazol-2-yl) Imidazolidine-2,4-Dione (6)}

A solution of compound $5(0.01 \mathrm{~mol})$ and benzaldhyde $(0.01 \mathrm{~mol})$ in glacial acetic acid $(5 \mathrm{ml})$ in the presence of anhydrous Sodium acetate $(0.8 \mathrm{gm})$ is heated under reflux for $12 \mathrm{~h}$. A precipitate is formed, after cooling, the solid is filtered off, recrystallized from acetic acid to afford Compound 6 as a white powder in $72 \%$ yield, $\mathrm{mp} 82^{\circ} \mathrm{C}-84^{\circ} \mathrm{C}$.

IR (KBR): v3284 (NH), $2850\left(\mathrm{CH}_{\text {aliphatic }}\right), 1683,1676(\mathrm{C}=\mathrm{O}), 1673(\mathrm{C}=\mathrm{N}) \mathrm{cm}^{-1}$. $1 \mathrm{H}-\mathrm{NMR}$ (DMSO-d6): $\delta 6.94,(\mathrm{~s}, 1 \mathrm{H}, \mathrm{D} 2 \mathrm{o}$ exchangeable, $\mathrm{NH}), \delta 7.6-7.3(\mathrm{~m}, 5 \mathrm{H}$, $\operatorname{ArH}), \delta 5.9(\mathrm{~s}, 1 \mathrm{H},=\mathrm{CH}), \delta 1.24\left(\mathrm{~m}, 32 \mathrm{H}, 16 \mathrm{CH}_{2}\right), \delta 0.88\left(\mathrm{t}, 3 \mathrm{H}, \mathrm{CH}_{3}\right)$.

MS m/z (\%): 510 (M+, 0.03), 421 (0.03), 324 (0.06), 115 (100), 89 (0.7).

Anal. Calc. (\%) for $\mathrm{C}_{29} \mathrm{H}_{4} \mathrm{~N}_{4} \mathrm{O}_{2} \mathrm{~S}$ : C, 68.20, H, 8.29, N, 10.97. Found: C, 68.35, $\mathrm{H}, 8.02, \mathrm{~N}, 11.04$.

\subsection{Synthesis of 4-((5-Heptadecyl-1,3,4-Thiadiazol-2-yl) Amino)-H-imidazole-2(5H)-Thione (7)}

Equimolar amounts of compound 2 and Thiourea in ethanol $(30 \mathrm{ml})$ in the presence of anhydrous Potassium carbonate $(0.5 \mathrm{gm})$, was heated under refluxed for $10 \mathrm{~h}$. The reaction mixture was concentrated, cooled. The solid product ob- 
tained was filtered off, dried and recrystallized from ethanol. Compound 7 was obtained as a yellow powder in $75 \%$ yield, $\mathrm{mp} 100^{\circ} \mathrm{C}-102^{\circ} \mathrm{C}$.

IR (KBR): v3370, 3177, (NH), $2920\left(\mathrm{CH}_{\text {aliphatic }}\right), 1662,1658(\mathrm{C}=\mathrm{N}), 1205(\mathrm{C}=\mathrm{S})$ $\mathrm{cm}^{-1} .1 \mathrm{H}-\mathrm{NMR}$ (DMSO-d6): $\delta 10.25,6.96(\mathrm{~s}, 1 \mathrm{H}, 2 \mathrm{NH}), \delta 2.78\left(\mathrm{~s}, 2 \mathrm{H}, \mathrm{CH}_{2}\right), \delta$ $1.24\left(\mathrm{~m}, 32 \mathrm{H}, 16 \mathrm{CH}_{2}\right), \delta 0.87\left(\mathrm{t}, 3 \mathrm{H}, \mathrm{CH}_{3}\right)$.

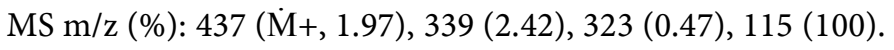

Anal. Calc. (\%) for $\mathrm{C}_{22} \mathrm{H}_{39} \mathrm{~N}_{5} \mathrm{~S}_{2}: \mathrm{C}, 60.37, \mathrm{H}, 8.98, \mathrm{~N} ; 16.00$. Found: C, 60.52, H, 8.82, N, 16.12 .

\subsection{Synthesis of 3-(5-Heptadecyl-1,3,4-Thiadiazol-2-yl)-2 Imino Thiazolidin-4-One (8)}

It was obtained from reaction of compound 2 with Potassium thiocyanate in acetone $(30 \mathrm{ml})$ in the presence of anhydrous Potassium carbonate $(0.5 \mathrm{gm})$, was heated for $2 \mathrm{~h}$. The reaction mixture was concentrated, cooled. The solid product obtained was filtered off, dried and recrystallized from ethanol. Compound 8 was obtained as a yellow powder in $70 \%$ yield, $\mathrm{mp} 80^{\circ} \mathrm{C}-82^{\circ} \mathrm{C}$.

IR (KBR): v3189, (=NH), $2919\left(\mathrm{CH}_{\text {aliphatic }}\right), 1680(\mathrm{C}=\mathrm{O}), 1659(\mathrm{C}=\mathrm{N}) \mathrm{cm}^{-1}$. 1H-NMR (DMSO-d6): $\delta 6.92,(\mathrm{~s}, 1 \mathrm{H}, \mathrm{D} 2 \mathrm{o}$ exchangeable, $=\mathrm{NH}), \delta 4.1(\mathrm{~s}, 2 \mathrm{H}$, $\mathrm{CH}), \delta 1.24\left(\mathrm{~m}, 32 \mathrm{H}, 16 \mathrm{CH}_{2}\right), \delta 0.87\left(\mathrm{t}, 3 \mathrm{H}, \mathrm{CH}_{3}\right)$.

MS m/z (\%):438 ( $\dot{\mathrm{M}}+, 75.24), 323$ (57.14), 226 (64.76), 115 (100).

Anal. Calc. (\%) for $\mathrm{C}_{22} \mathrm{H}_{38} \mathrm{~N}_{4} \mathrm{OS}_{2}$ : C, 60.23, H, 8.73, N, 12.77. Found: C, 60.40, $\mathrm{H}, 8.56, \mathrm{~N}, 12.87$.

\subsection{Synthesis of (Z)-5-Benzylidene-3-(5-Heptadecyl-1,3,4 Thiadiazol-2-yl) Imino Thiazolidin-4-One (9)}

Equimolar quantities of 8 and benzaldhyde in glacial acetic acid $(5 \mathrm{ml})$ in the presence of anhydrous Sodium acetate $(0.8 \mathrm{gm})$ are heated under reflux for $10 \mathrm{~h}$. after which a precipitate is formed, on cooling, the solid is filtered off, recrystallized from acetic acid to afford Compound 9 was obtained as a pale yellow powder in $75 \%$ yield, $\mathrm{mp} 85^{\circ} \mathrm{C}-87^{\circ} \mathrm{C}$.

IR (KBR): $v 3426(=\mathrm{NH}), 2919\left(\mathrm{CH}_{\text {aliphatic }}\right), 1682,(\mathrm{C}=\mathrm{O}), 1666(\mathrm{C}=\mathrm{N}) \mathrm{cm}^{-1}$. $1 \mathrm{H}-\mathrm{NMR}$ (DMSO-d6): $\delta 6.95,(\mathrm{~s}, 1 \mathrm{H}, \mathrm{D} 2 \mathrm{o}$ exchangeable, $=\mathrm{NH}), \delta 7.6-7.3,(\mathrm{~m}$, $5 \mathrm{H}, \mathrm{ArH}), \delta 1.24\left(\mathrm{~m}, 32 \mathrm{H}, 16 \mathrm{CH}_{2}\right), \delta 0.85\left(\mathrm{t}, 3 \mathrm{H}, \mathrm{CH}_{3}\right)$.

MS m/z (\%): 526 (M+, 0.18), 323 (0.29), 115 (100), 89 (0.23).

Anal. Calc. (\%) for $\mathrm{C}_{29} \mathrm{H}_{42} \mathrm{~N}_{4} \mathrm{OS}_{2}$ : C, 66.12, $\mathrm{H}, 8.01, \mathrm{~N}, 10.64$. Found: C, 66.42, $\mathrm{H}, 7.90, \mathrm{~N}, 10.76$.

\subsection{Antimicrobial Activities}

Screening of The antimicrobial activity of the synthesized compounds was evaluated using modified Kirby-Bauer disc diffusion technique [20] [21] [22] [23], using Mueller-Hinton agar. In $10 \mathrm{ml}$ of fresh media, one hundred micro liters of the test bacteria/fungi were grown until to be approximately 108 cells $/ \mathrm{ml}$ for bacteria and 105 cells/ml for fungi. Ampicillin and Amphotericin B were used as a standard drugs as a positive control for antibacterial and antifungal activity, 
Table 1. Antimicrobial activity of compounds $1-9$.

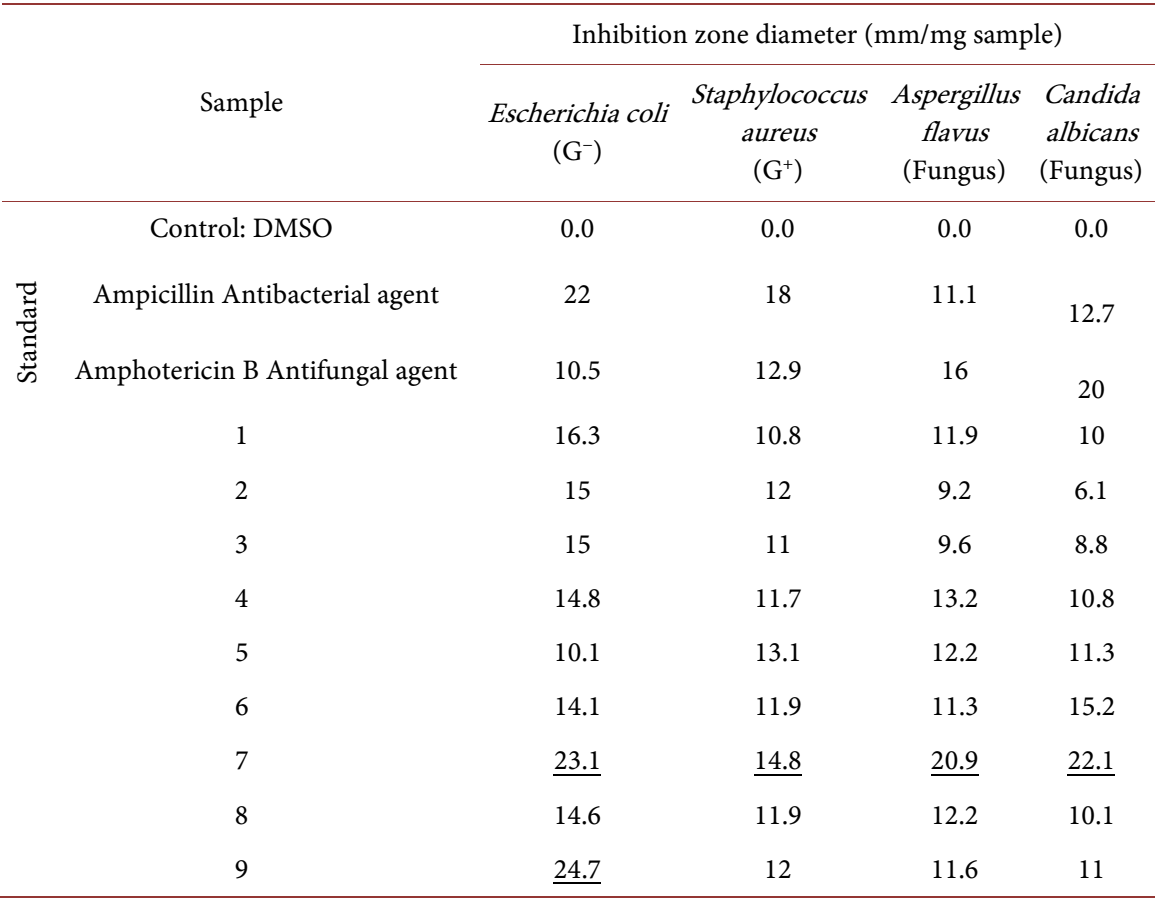

respectively. Filter discs immersed with $10 \mu \mathrm{l}$ of solvent (distilled water, chloroform, DMSO) and used as a negative control, then a blank paper discs with a diameter of $8.0 \mathrm{~mm}$ were impregnated with $10 \mu \mathrm{l}$ of the tested concentration. (100 $\mu l)$ was spread onto agar plates that are relevant to the broth in which they are maintained. Standard discs of c (Antibacterial agent), Amphotericin B (Antibacterial agent)were used as positive control for antimicrobial activity, while filter discs impregnated with $10 \mu \mathrm{l}$ of solvent (distilled water, chloroform, DMSO) were used as a negative control. Blank paper discs (Schleicher and Schuell, Spain) with a diameter of $8.0 \mathrm{~mm}$ were impregnated with $10 \mu \mathrm{l}$ of the tested concentration. The obtained data on the antimicrobial activity of the compounds are shown in Table 1.

\subsection{Propoxylation}

Using Morgos procedure [24], $0.01 \mathrm{~mol}$ of the synthesized compound was stirred with $0.5 \mathrm{wt} \% \mathrm{KOH}$ solution and heated to $70^{\circ} \mathrm{C}$ slow stream of nitrogen. The nitrogen stream was stopped after flushing out oxygen, then propylene oxide in different moles ( 3,5 and 7 mole) was added using a syringe drop-wise with continuous stirring under reflux. The reaction was conducted for different intervals of time (1/2 - 1 h). After cooling, the flask was weighed, and the average degree of propoxylation determined from increment in the mass of the reaction mixture [25].

\section{Surface Active Properties}

\subsection{Surface and Interfacial Tensions}

Measurements of Surface and interfacial tension of $2_{(\mathrm{a}-\mathrm{c})}-9_{(\mathrm{a}-\mathrm{c})}$ were measured by 
Findlay [26] with a Krüss tensiometer [27], at different concentrations (0.05 $\left.10^{-6} \mathrm{~mol} / \mathrm{L}\right)$ of the synthesized surfactant, and at constant temperature $\left(25^{\circ} \mathrm{C} \pm\right.$ $1^{\circ} \mathrm{C}$ ) for the interfacial measurements, Paraffin oil and The tensiometer was calibrated using ASTM: D1331-01 method [28].

\subsection{Cloud Point}

The cloud point was determined by gradual heating of $1.0 \mathrm{wt} \%$ solution in a controlled temperature bath and the temperature at which the clear or nearly clear solution becomes turbid was recorded [29]. It is a measure of the inverse solubility of a nonionic surfactants, the reproducibility of this is checked by clearing the solution again by cooling.

\subsection{Wetting Time}

Draves test used to measure the Wetting time [30], of the prepared surfactants by immersing a cotton fabric in a $0.1 \mathrm{wt} \%$ aqueous solution of the tested surfactant and measuring The sinking time in seconds.

\subsection{Foaming Properties}

In a volumetric cylinder, $1.0 \mathrm{wt} \%$ solution of the tested surfactant was checked and allowed to fall from a set height initially produced and the height of the foam is measured according the Ross Miles method [31].

\subsection{Emulsion Stability}

The emulsion was prepared by stirring $(10 \mathrm{ml}, 20 \mathrm{mml})$ of aqueous solution of the tested surfactant and $6 \mathrm{ml}$ of light paraffin oil using magnetic stirrer. After the mixture was vigorously shaken, it was allowed to separate the emulsion and the time taken for about $(9 \mathrm{ml})$ of the aqueous layer separation express the emulsion stability of the surfactant [32].

\section{6. (CMC) Measurements}

The critical micelle concentration (CMC) of a surfactant is the concentration at which the solution shows an abrupt change, where the surface active ions in the solution aggregates to form larger units called micelles [33]. Generally, the nonionic surfactants have lower CMC values than their alternative ionic surfactants, and the value obtained as a plot of logarithm of the surfactant concentration versus the surface tension.

\subsection{Effectiveness $\left(\pi_{\mathrm{CMC}}\right)$}

Decreasing in surface tension induced by a surfactant molecule at the critical micelle concentration is the effectiveness $\left(\pi_{\mathrm{CMC}}\right)$ of this surfactants and this can be calculated from difference between surface tension of the pure water $\left(\gamma_{0}\right)$ and the surface tension of the surfactant solution at the critical micelle concentration [34], $\left(\gamma_{\mathrm{CMC}}\right)$, Equation (1). 


$$
\pi_{\mathrm{CMC}}=\gamma_{0}-\gamma_{\mathrm{CMC}}
$$

\subsection{Efficiency}

The value of negative logarithm of the bulk concentration necessary to reduce surface tension by $20 \mathrm{mN} / \mathrm{m}$ is known as efficiency of the surfactant $\left(\mathrm{PC}_{20}\right)$ [35], and can be calculated from the following equation, Equation (2).

$$
\mathrm{PC}_{20}=\frac{\gamma-20-\gamma_{C M C}}{2.303 n R T}-\log C_{\mathrm{CMC}}
$$

where $T$ is absolute temperature in Kelvin and $R$ is the universal gas constant $8.31 \times 10^{7} \mathrm{ergs} \mathrm{mol}^{-1} \mathrm{~K}^{-1}$.

\subsection{Maximum Surface Excess $\Gamma_{\max }$}

Using Gibbs equation (Equation (3)) and values of surface and interfacial tension, the maximum surface excess $\Gamma_{\max }$ can be calculated Equation (3):

$$
\Gamma_{\max }=\frac{-1}{2.303} R T\left(\frac{\delta \gamma}{\delta \log C}\right)_{T}
$$

where $\delta \gamma$ surface pressure in $\mathrm{mN} / \mathrm{m}, C$ surfactant concentration and $(\delta \gamma / \delta \log C)_{T}$ is the slope of surface tension versus concentration curves below CMC at constant temperature[36].

\subsection{Minimum Surface Area $\left(A_{\min }\right)$}

The average area $A_{\min }(\AA / \mathrm{mol})$ occupied by each surfactant molecule and adsorbed at the saturated air/water interface have been calculated easily from $\Gamma_{\max }$ values using the following equation [37] [38] (Equation (4)).

$$
A_{\min }=10^{16} / \Gamma_{\max } N
$$

where $N$ Avogadro's number $6.023 \times 10^{23}$.

\section{Hydrolysis Resistance}

Resistance of decomposition of surfactant molecule in aqueous solutions even under extreme $\mathrm{PH}$ and temperature conditions was established by surface tension measurements of that surfactant (0.1\%) solution in $5 \%$ sulfuric acid or $1 \%$ sodium hydroxide at ambient temperature.

\section{Biodegradability of the Synthesized Surfactants}

Die-Away method [39] or River test was used to test the biodegradation of the synthesized nonionic surfactants in River water. In this method samples were drawn daily, filtered and the surface tension was measured using Du-Nouy tensiometer through 7 days and the biodegradation percentage D\% was calculated from the following Equation (5).

$$
D=\left[\left(\gamma_{t}-\gamma_{0}\right) /\left(\gamma_{b t}-\gamma_{0}\right)\right] \times 100
$$

where $\gamma_{t}$ surface tension at time $t, \gamma_{0}$ surface tension at time zero (initial surface 
tension). $\gamma_{b t}$ surface tension of the blank experiment at time $t$.

\section{Results and Discussion}

Treatment of Stearic acid with Thiosemicarbaziede in phosphorous oxy chloride produce 2-amino-5-heptadecyl-1,3,4-Thiadiazole-2-amine (1) [40].

Chlorination of the free amino group by chloroacetyl chloride yielded 2-chlorothiadiazolyl acetamide derivative (2) in good yield, which showed $v \mathrm{c}=\mathrm{o}$ of amide at $1681 \mathrm{~cm}^{-1}$ and its IR spectrum, and mass spectrum showed $[\dot{\mathrm{M}}+]$ And $[\dot{\mathrm{M}}++2]$ at $(415,14.3 \%)$, and $(417,11.8 \%)$ respectively. The chlorothiadiazolyl acetamide (2) reacts with Piperidine in absolute ethanol and anhydrous $\mathrm{K}_{2} \mathrm{CO}_{3}$ and furnished N-(5-heptadecyl-1,3,4-Thiadiazol-2-yl)-2-(Piperidin-1-yl) acetamide (3). Its mass spectrum elucidated the structure and indicate the presence of $[\dot{\mathrm{M}}+]$ at $(464,1.2 \%)$, and $[\dot{\mathrm{M}}++2]$ at $(466,0.16 \%)$ and the fragmentation pattern (Figure 1) supported these structures and the mass fragmentation of compound 4 is presented in (Figure 2). Also the mass fragmentation compounds 7.9 are presented in (Figure 3 ) and (Figure 4) respectively. Heterolytic addition of low molecular weight alcohols to the $\mathrm{C}=\mathrm{N}$ of thiadiazole has been reported for the photochemical reactions [41] [42].

By the same manner, piperazine reacts with compound (2) and produced $\mathrm{N}$-(5-heptadecyl-1,3,4-Thiadiazol-2-yl)-2-(piperazin-1-yl) acetamide 4 and its IR exhibits the presence of two $v_{\mathrm{NH} \text { 's }}$ at $3281,3110 \mathrm{~cm}^{-1}$ while the mass spectra showed $\left[\dot{\mathrm{M}}^{+}\right]$at $(465,0.9 \%),\left[\dot{\mathrm{M}}^{+}+1\right]$ at $(466,0.18 \%)$, which supported by the fragmentation pattern of the structure, Figure 2.

Reaction of compound (2) with urea and thiourea in boiling ethanol and in the presence of potassium carbonate yielded Thiadiazolidine-dione (5) and thiadiazolyl imidazole thione (7) respectively and when compound (5) allowed to condense with benzaldehyde in refluxing glacial acetic acid produced (Z)-5-benzylidene-3-(5-heptadecyl-1,3,4 Thiadiazol-2-yl) imidazolidine-2,4-dione (6).

On the other hand, when compound (2) refluxed with potassium thiocyanate in dry acetone and in the presence of anhydrous potassium carbonate furnished the thiadiazolyl imithiazolidinone, which upon condensation with benzaldehyde, the (Z)-5-benzylidene-3-(5-heptadecyl-1,3,4 Thiadiazol-2-yl) iminothiadazolidine-4-one (9) obtained.

\subsection{Antimicrobial Activities}

The antimicrobial activity of the synthesized compounds (1-9) were investigated in vitro (using a modified Kirby-Bauer disc diffusion method against two bacterial strains namely, Escherichia coli (Gram-ve), and Staphylococcus aureus Gram $+\mathrm{ve}$ ) and two fungal species namely, Aspergillus flavus and Candida albicans With Ampicilline and Amphotericin B as a positive references for antibacterial and antifungal agents, respectively and shown in Table 1 . As shown in Table 1 , the synthesized compounds showed variable inhibition efficiency against the tested microorganisms. Compounds ( $3-5$ and 8$)$ exhibit moderate 


$$
\mathrm{RCOOH}+\mathrm{H}_{2} \mathrm{NHN}-\mathrm{C}-\mathrm{NH}_{2} \frac{\mathrm{POCL}_{3}}{6 \mathrm{hr}} \underset{\mathrm{R}=\mathrm{C}_{17} \mathrm{H}_{35}}{\longrightarrow}
$$

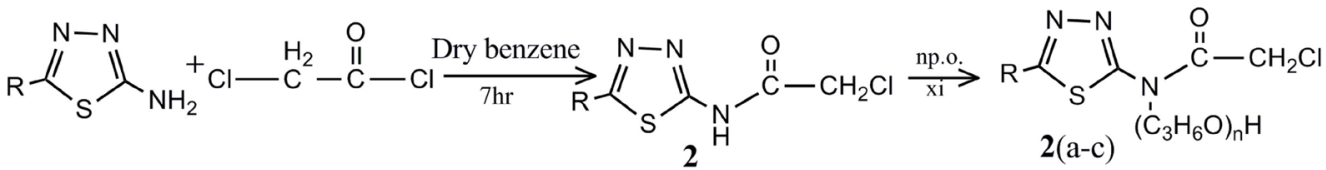

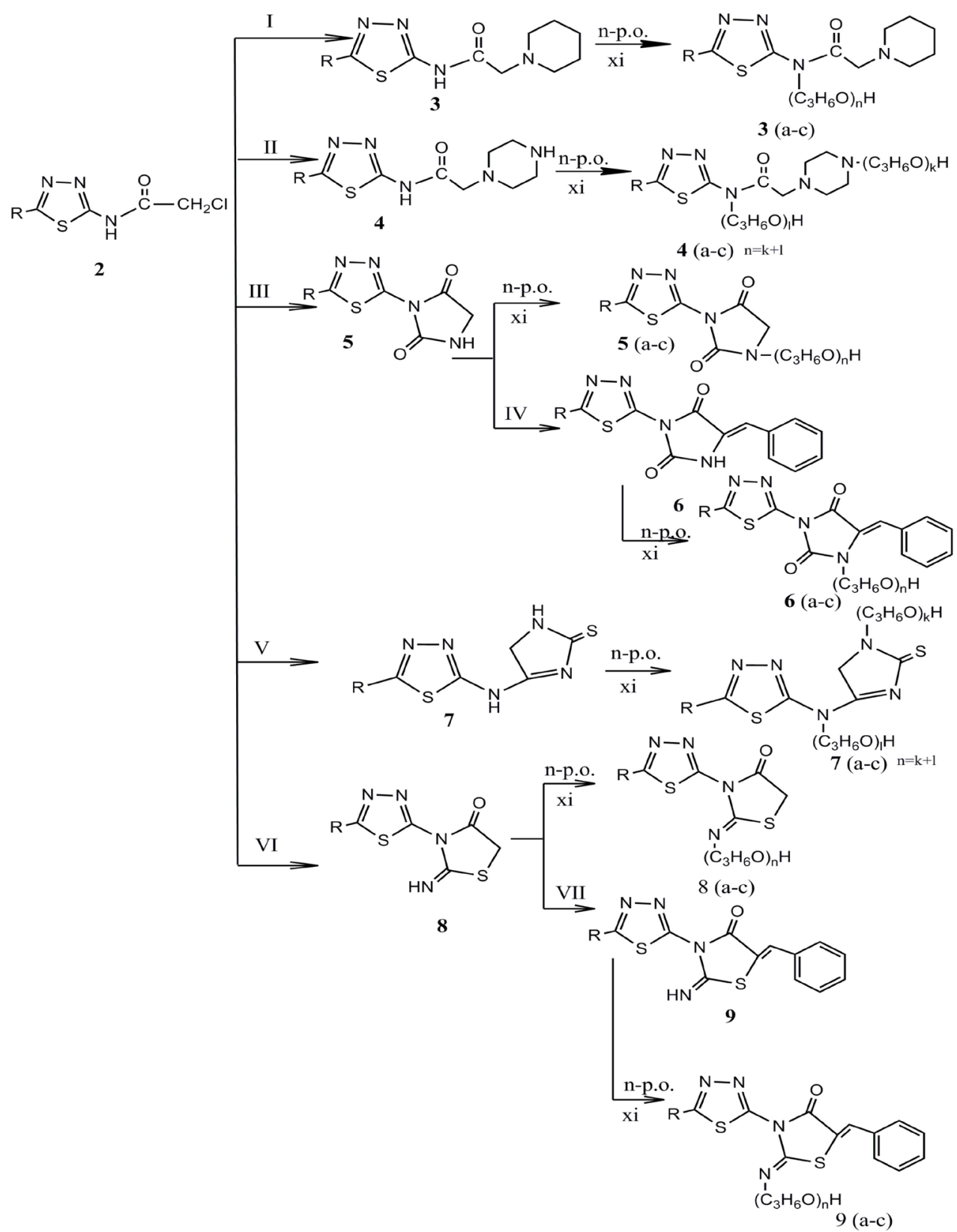

Scheme 1. Synthetic routes of compounds of (1 - 9) and surfactants $\left(1_{(\mathrm{a}-\mathrm{c})}-9_{(\mathrm{a}-\mathrm{c})}\right)$. (I) piperidine, ethanol, anhydrous $\mathrm{K}_{2} \mathrm{CO}_{3}$ reflux $6 \mathrm{hr}$. (II) piperazine, ethanol, anhydrous $\mathrm{K}_{2} \mathrm{CO}_{3}$ reflux $6 \mathrm{hr}$. (III) Urea, ethanol, anhydrous $\mathrm{K}_{2} \mathrm{CO}_{3}$ reflux $10 \mathrm{hr}$. (IV) benzaldehyde, glacial acetic acid, anhydrous sodium acetate, reflux $10 \mathrm{hr}$. (V) thiourea, ethanol, anhydrous $\mathrm{K}_{2} \mathrm{CO}_{3}$ reflux $10 \mathrm{hr}$. (VI) Potassium thiocyanate, acetone, anhydrous $\mathrm{K}_{2} \mathrm{CO}_{3}$ reflux $2 \mathrm{hr}$. (VII) benzaldehyde, glacial acetic acid, anhydrous sodium acetate, reflux $10 \mathrm{hr}$. (XI) $\mathrm{n}=3,5$ and $7 \mathrm{~mol}$ of propylene oxide (P.o.). 


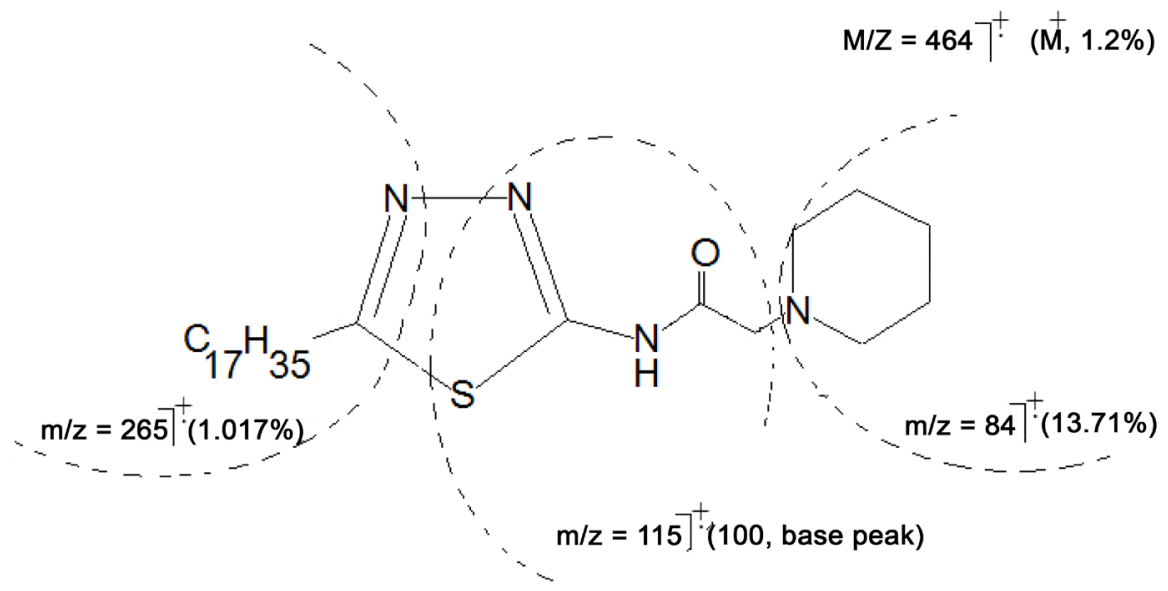

Figure 1. Mass fragmentation of compound 3.

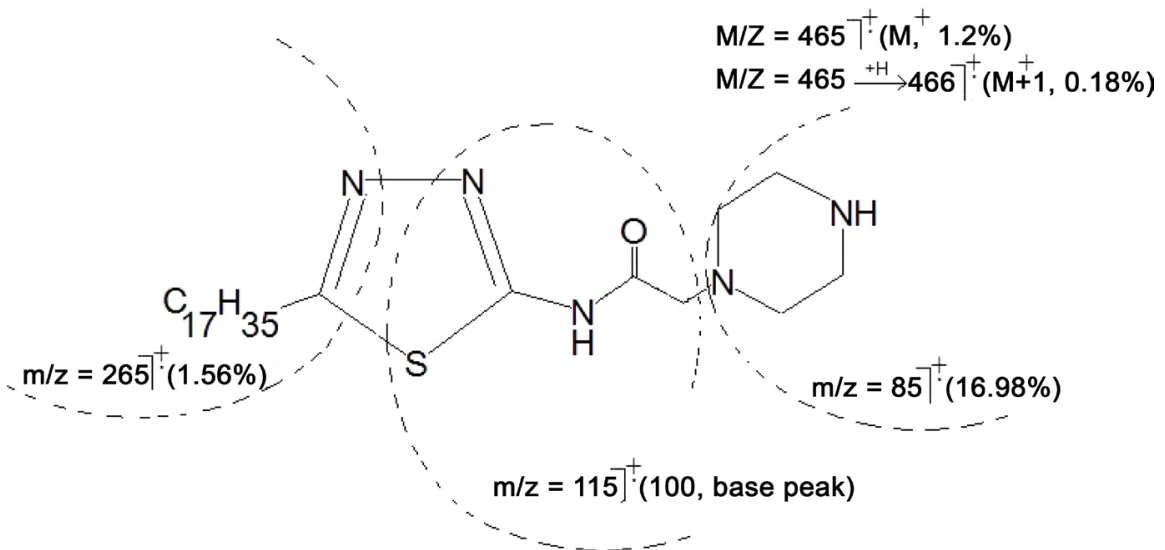

Figure 2. Mass fragmentation of compound 4.

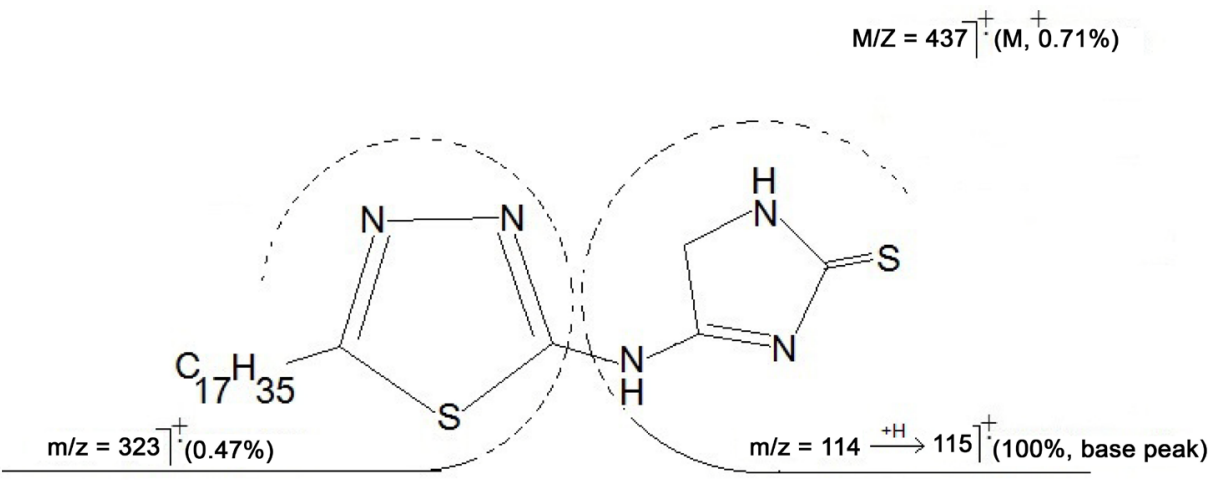

Figure 3. Mass fragmentation of compound 7.

activity towards both tested fungi and bacterial strains. While, compound (7) showed the highest activity towards the tested microorganisms. Which may be possibly due to the presence of the =N-C-S moiety. On the other side, compounds (6 and 9) revealed good activity towards both bacterial and fungal species. These results are in agreement with previously reported results for thiadiazole derivatives [43] [44] [45] [46]. 


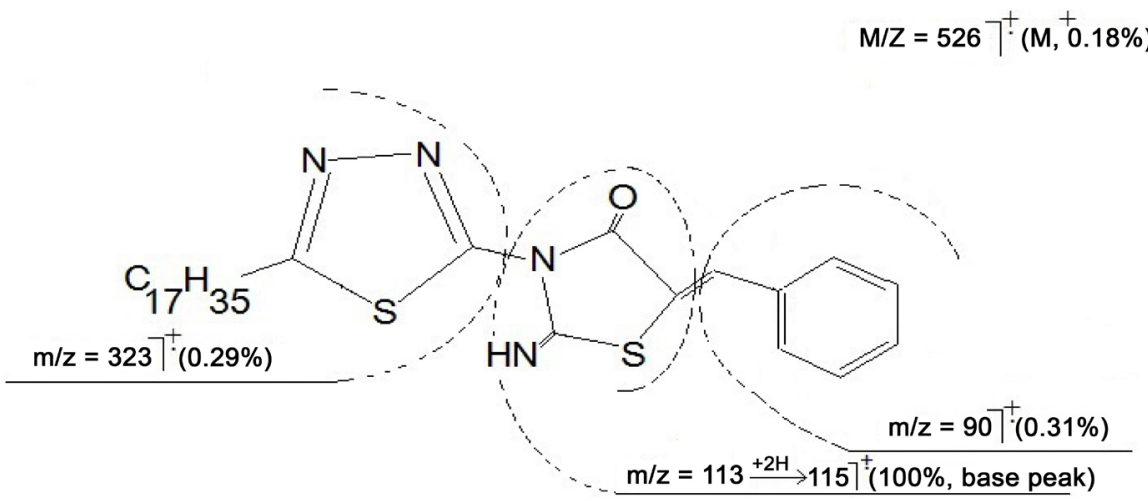

Figure 4. Mass fragmentation of compound 9.

\subsection{Nonionic Surfactants from the Synthesized Compounds}

Addition of propylene oxide in different moles $(3,5$ and $7 \mathrm{~mol})$ to the new synthesized compounds $(2-9)$ produced the nonionic surfactants $2_{(\mathrm{a}-\mathrm{c})}-9_{(\mathrm{a}-\mathrm{c})}$ which elucidated via their IR and ${ }^{1} \mathrm{H}-\mathrm{NMR}$ spectra.

IR spectrum of these compounds showed a broad band in the region (3.500 $2.500) \mathrm{cm}^{-1}$ and two other bands in the region of $(1100-1000) \mathrm{cm}^{-1}$ and $(950-$ $900) \mathrm{cm}^{-1}$, which attributed to $(\nu \mathrm{OH})$ and $(\nu \mathrm{C}-\mathrm{O}-\mathrm{C})$ ether linkage, respectively, in addition to the other bands reported for these compounds. ${ }^{1} \mathrm{H}$-NMR spectrum showed the propyleneoxy group protons as multiple signals with the chemical shift (3.5 - 3.7) ppm. The physical properties of these compounds are dipped in Table 2.

\subsection{Surface Active Properties}

The surface active properties of the new propoxylated compounds $2_{(\text {a-c })}$ to $9_{(\text {a-c })}$ were evaluated in a neutral medium, and the data obtained are listed in Table 3(a), Table 3(b).

\subsection{Surface and Interfacial Tensions}

The ability of surfactants to lower the surface and interfacial tension make them available for large number of applications [47]. As their molecules dissociate in water, they weaken the hydrogen bond by orientate themselves in-between the water molecules, which decreases the holding forces and lowers the surface and interfacial tension. The surface and Interfacial Tensions of the new synthesized surfactants increases by increasing the number of propylene oxide units (Table $3(a)$ ), which may be attributed to increase the attractive forces and this is in accordance with the previously reported results [48].

\subsection{Cloud Point}

The temperature above which an aqueous solution of surfactants becomes turbid and separates into two phases is the cloud point of surfactant. It is considered effective when used near or below the cloud point, which is helping in determination of the storage stability. The cloud point depends on the chemical struc- 
ture [49] [50], and it was reported that it increase with increasing the hydrophilic part [51] [52], and this is compatible with our results (Table 3(a)).

\subsection{Wetting Time}

In terms of wetting time, the synthesized nonionic surfactants efficiency was measured according to Draves technique. Shorter the time of surfactant to wet a piece of cotton fibre indicates the more efficiency of the surfactant as wetting agent. As shown in (Table 3 ), surfactants $2_{(\mathrm{a}-\mathrm{c})}$ to $9_{(\mathrm{a}-\mathrm{c})}$ exhibits various wetting abilities, which in general decreased with increasing the number of moles of propylene oxide, and this may be due to increasing the adhesive forces relatively to the cohesive forces [53].

Table 2. Physicochemical properties of the synthesized surfactants.

\begin{tabular}{|c|c|c|c|c|}
\hline Compound & M.F. & M.wt & Color & Shape \\
\hline 1a & $\mathrm{C}_{28} \mathrm{H}_{55} \mathrm{~N}_{3} \mathrm{O}_{3} \mathrm{~S}$ & 513 & Yellow & Semi Solid \\
\hline $1 b$ & $\mathrm{C}_{34} \mathrm{H}_{67} \mathrm{~N}_{3} \mathrm{O}_{5} \mathrm{~S}$ & 629 & Yellow & Semi Solid \\
\hline $1 c$ & $\mathrm{C}_{40} \mathrm{H}_{79} \mathrm{~N}_{3} \mathrm{O}_{7} \mathrm{~S}$ & 745 & Yellow & Semi Solid \\
\hline $2 \mathrm{a}$ & $\mathrm{C}_{30} \mathrm{H}_{56} \mathrm{~N}_{3} \mathrm{O}_{4} \mathrm{SCl}$ & 591 & Yellow & Semi Solid \\
\hline $2 b$ & $\mathrm{C}_{36} \mathrm{H}_{68} \mathrm{~N}_{3} \mathrm{O}_{6} \mathrm{SCl}$ & 707 & Yellow & Semi Solid \\
\hline $2 c$ & $\mathrm{C}_{42} \mathrm{H}_{80} \mathrm{~N}_{3} \mathrm{O}_{8} \mathrm{SCl}$ & 823 & Yellow & Semi Solid \\
\hline $3 a$ & $\mathrm{C}_{35} \mathrm{H}_{66} \mathrm{~N}_{4} \mathrm{O}_{4} \mathrm{~S}$ & 638 & Yellow & Powder \\
\hline $3 b$ & $\mathrm{C}_{41} \mathrm{H}_{78} \mathrm{~N}_{4} \mathrm{O}_{6} \mathrm{~S}$ & 754 & Yellow & Powder \\
\hline $3 c$ & $\mathrm{C}_{47} \mathrm{H}_{90} \mathrm{~N}_{4} \mathrm{O}_{8} \mathrm{~S}$ & 870 & Yellow & Powder \\
\hline $4 a$ & $\mathrm{C}_{43} \mathrm{H}_{83} \mathrm{~N}_{5} \mathrm{O}_{7} \mathrm{~S}$ & 813 & Yellow & Semi Solid \\
\hline $4 b$ & $\mathrm{C}_{55} \mathrm{H}_{107} \mathrm{~N}_{5} \mathrm{O}_{11} \mathrm{~S}$ & 1045 & Brown & Semi Solid \\
\hline $4 c$ & $\mathrm{C}_{67} \mathrm{H}_{131} \mathrm{~N}_{5} \mathrm{O}_{15} \mathrm{~S}$ & 1277 & Dark Brown & Semi Solid \\
\hline $5 \mathrm{a}$ & $\mathrm{C}_{31} \mathrm{H}_{58} \mathrm{~N}_{4} \mathrm{O}_{5} \mathrm{~S}$ & 598 & Yellow & Semi Solid \\
\hline $5 b$ & $\mathrm{C}_{37} \mathrm{H}_{70} \mathrm{~N}_{4} \mathrm{O}_{7} \mathrm{~S}$ & 714 & Brown & Semi Solid \\
\hline $5 c$ & $\mathrm{C}_{43} \mathrm{H}_{82} \mathrm{~N}_{4} \mathrm{O}_{9} \mathrm{~S}$ & 830 & Dark Brown & Semi Solid \\
\hline $6 a$ & $\mathrm{C}_{38} \mathrm{H}_{60} \mathrm{~N}_{4} \mathrm{O}_{5} \mathrm{~S}$ & 684 & Yellow & Powder \\
\hline $6 \mathrm{~b}$ & $\mathrm{C}_{44} \mathrm{H}_{72} \mathrm{~N}_{4} \mathrm{O}_{7} \mathrm{~S}$ & 800 & Yellow & Powder \\
\hline $6 c$ & $\mathrm{C}_{50} \mathrm{H}_{84} \mathrm{~N}_{4} \mathrm{O}_{9} \mathrm{~S}$ & 916 & Yellow & Powder \\
\hline $7 \mathrm{a}$ & $\mathrm{C}_{40} \mathrm{H}_{75} \mathrm{~N}_{5} \mathrm{O}_{6} \mathrm{~S}_{2}$ & 785 & Yellow & Semi Solid \\
\hline $7 b$ & $\mathrm{C}_{52} \mathrm{H}_{99} \mathrm{~N}_{5} \mathrm{O}_{10} \mathrm{~S}_{2}$ & 1017 & Brown & Semi Solid \\
\hline $7 c$ & $\mathrm{C}_{64} \mathrm{H}_{123} \mathrm{~N}_{5} \mathrm{O}_{14} \mathrm{~S}_{2}$ & 1249 & Dark Brown & Semi Solid \\
\hline $8 \mathrm{a}$ & $\mathrm{C}_{31} \mathrm{H}_{56} \mathrm{~N}_{4} \mathrm{O}_{4} \mathrm{~S}_{2}$ & 612 & Yellow & Semi Solid \\
\hline $8 b$ & $\mathrm{C}_{37} \mathrm{H}_{68} \mathrm{~N}_{4} \mathrm{O}_{6} \mathrm{~S}_{2}$ & 728 & Brown & Semi Solid \\
\hline $8 c$ & $\mathrm{C}_{43} \mathrm{H}_{80} \mathrm{~N}_{4} \mathrm{O}_{8} \mathrm{~S}_{2}$ & 844 & Dark Brown & Semi Solid \\
\hline $9 \mathrm{a}$ & $\mathrm{C}_{38} \mathrm{H}_{60} \mathrm{~N}_{4} \mathrm{O}_{4} \mathrm{~S}_{2}$ & 700 & Yellow & Semi Solid \\
\hline $9 b$ & $\mathrm{C}_{44} \mathrm{H}_{72} \mathrm{~N}_{4} \mathrm{O}_{6} \mathrm{~S}_{2}$ & 816 & Brown & Semi Solid \\
\hline $9 c$ & $\mathrm{C}_{50} \mathrm{H}_{84} \mathrm{~N}_{4} \mathrm{O}_{8} \mathrm{~S}_{2}$ & 932 & Dark Brown & Semi Solid \\
\hline
\end{tabular}


Table 3. Surface properties of some synthesized surfactants.

(a)

\begin{tabular}{|c|c|c|c|c|c|c|c|}
\hline Compound & No. of molesa & $\begin{array}{l}\text { Surface tension } \\
(\mathrm{mN} / \mathrm{m}) 0.1 \mathrm{wt} \%\end{array}$ & $\begin{array}{c}\text { Interfacial tension } \\
(\mathrm{mN} / \mathrm{m}) 0.1 \mathrm{wt} \%\end{array}$ & $\begin{array}{l}\text { Cloud point } \\
\left({ }^{\circ} \mathrm{C}\right) 1.0 \mathrm{wt} \%\end{array}$ & $\begin{array}{l}\text { Wetting time } \\
\text { (s) } 1.0 \mathrm{wt} \%\end{array}$ & $\begin{array}{l}\text { Foam height } \\
(\mathrm{mm}) 1.0 \mathrm{wt} \%\end{array}$ & $\begin{array}{l}\text { Emulsion stability } \\
\text { (min) } 20 \mathrm{~mol}\end{array}$ \\
\hline \multirow{3}{*}{$\begin{array}{c}(a) \\
2(a-c)\end{array}$} & 3 & 32 & 10 & 83 & 46 & 70 & 43 \\
\hline & 5 & 33 & 11 & 90 & 44 & 80 & 42 \\
\hline & 7 & 35 & 12 & 96 & 40 & 90 & 40 \\
\hline \multirow{3}{*}{$3(a-c)$} & 3 & 30 & 11 & 82 & 44 & 80 & 46 \\
\hline & 5 & 32 & 13 & 96 & 42 & 90 & 44 \\
\hline & 7 & 33 & 14 & 96 & 38 & 100 & 46 \\
\hline \multirow{3}{*}{$4(a-c)$} & 3 & 31 & 12 & 86 & 50 & 80 & 50 \\
\hline & 5 & 32 & 13 & 95 & 46 & 100 & 45 \\
\hline & 7 & 35 & 14 & 100 & 42 & 120 & 40 \\
\hline \multirow{3}{*}{$5(a-c)$} & 3 & 30 & 12 & 82 & 44 & 60 & 44 \\
\hline & 5 & 32 & 13 & 90 & 40 & 70 & 40 \\
\hline & 7 & 34 & 14 & 95 & 35 & 80 & 38 \\
\hline \multirow{3}{*}{$6(a-c)$} & 3 & 30 & 11 & 85 & 50 & 70 & 45 \\
\hline & 5 & 32 & 12 & 90 & 45 & 80 & 42 \\
\hline & 7 & 36 & 13 & 95 & 42 & 90 & 40 \\
\hline \multirow{3}{*}{$7(a-c)$} & 3 & 30 & 11 & 86 & 46 & 90 & 55 \\
\hline & 5 & 32 & 12 & 95 & 43 & 110 & 50 \\
\hline & 7 & 36 & 16 & 100 & 40 & 120 & 45 \\
\hline \multirow{3}{*}{$8(a-c)$} & 3 & 33 & 10 & 82 & 46 & 80 & 40 \\
\hline & 5 & 31 & 11 & 90 & 43 & 90 & 38 \\
\hline & 7 & 32 & 13 & 96 & 40 & 100 & 35 \\
\hline \multirow{3}{*}{$9(a-c)$} & 3 & 31 & 11 & 86 & 44 & 90 & 44 \\
\hline & 5 & 33 & 13 & 92 & 42 & 95 & 42 \\
\hline & 7 & 36 & 16 & 96 & 30 & 110 & 38 \\
\hline
\end{tabular}

(b)

\begin{tabular}{|c|c|c|c|c|c|c|c|}
\hline Compound & No. of molesa & $\mathrm{CMC}(\mathrm{mmol} / \mathrm{l})$ & $\gamma_{\mathrm{CMC}}(\mathrm{mmol} / \mathrm{l})$ & $\pi_{\mathrm{CMC}} \mathrm{mN} / \mathrm{m}$ & $\mathrm{PC}_{20}(\mathrm{mmol} / \mathrm{l})$ & $\Gamma_{\max }\left(\mathrm{mol} / \mathrm{cm}^{2}\right)$ & $A_{\min }(\AA 2 / \mathrm{mol})$ \\
\hline \multirow{3}{*}{$\begin{array}{c}(b) \\
2(a-c)\end{array}$} & 3 & 10.0 & 34.5 & 37.5 & 2.00 & 0.95 & 1.73 \\
\hline & 5 & 12.0 & 37.5 & 34.5 & 1.92 & 1.82 & 0.91 \\
\hline & 7 & 19.9 & 39 & 33 & 1.70 & 2.19 & 0.75 \\
\hline \multirow{3}{*}{$3(a-c)$} & 3 & 3.1 & 29 & 43 & 2.51 & 0.84 & 1.97 \\
\hline & 5 & 3.9 & 31 & 41 & 2.41 & 1.62 & 1.02 \\
\hline & 7 & 5.4 & 34 & 38 & 2.27 & 1.97 & 0.84 \\
\hline \multirow{3}{*}{$4(a-c)$} & 3 & 0.64 & 32 & 40 & 3.19 & 0.98 & 1.65 \\
\hline & 5 & 0.95 & 35.5 & 36.5 & 3.02 & 1.88 & 0.87 \\
\hline & 7 & 1.9 & 38 & 34 & 2.72 & 2.26 & 0.72 \\
\hline \multirow{3}{*}{$5(a-c)$} & 3 & 4.0 & 31 & 41 & 2.40 & 0.80 & 2.06 \\
\hline & 5 & 5.6 & 33 & 39 & 2.25 & 1.55 & 1.70 \\
\hline & 7 & 9.0 & 35 & 37 & 2.05 & 1.89 & 0.87 \\
\hline \multirow{3}{*}{$6(a-c)$} & 3 & 2.0 & 35 & 37 & 2.70 & 0.97 & 1.70 \\
\hline & 5 & 4.5 & 36.5 & 35.5 & 2.35 & 1.85 & 0.89 \\
\hline & 7 & 11.0 & 39 & 33 & 1.96 & 2.23 & 0.74 \\
\hline \multirow{3}{*}{$7(a-c)$} & 3 & 8.9 & 38 & 34 & 1.85 & 1.14 & 1.44 \\
\hline & 5 & 12.0 & 42 & 30 & 1.23 & 2.15 & 0.77 \\
\hline & 7 & 14.0 & 45 & 27 & 1.09 & 2.57 & 0.64 \\
\hline \multirow{3}{*}{$8(a-c)$} & 3 & 3.8 & 30 & 42 & 2.42 & 0.79 & 2.05 \\
\hline & 5 & 5.1 & 33 & 39 & 2.29 & 1.59 & 1.09 \\
\hline & 7 & 6.0 & 34 & 38 & 2.22 & 1.89 & 0.87 \\
\hline \multirow{3}{*}{$9(a-c)$} & 3 & 5.3 & 34 & 38 & 2.28 & 0.98 & 1.68 \\
\hline & 5 & 7.7 & 35 & 37 & 2.11 & 1.87 & 0.88 \\
\hline & 7 & 10.7 & 38 & 34 & 1.97 & 2.25 & 0.73 \\
\hline
\end{tabular}

a Number of propylene oxide units 


\subsection{Foaming Power}

By lowering the surface tension, the surfactant molecule help in foam simultaneous adsorption of the surfactant molecules onto the interface between gas and liquid interface. Using the Ross Miles method, the foam power of the synthesized nonionic surfactant was measured and the data depicted in Table 3 showed that as the number of moles of propylene oxide increase, the foam height increased, which in agreement with previously reported [53] [54] [55].

\subsection{Emulsion Stability}

The ability of the prepared surfactant to form emulsions spread their applications, thus the emulsifying power of these surfactants was measured in term of time needed for $9 \mathrm{ml}$ of the solution is presented in Table 3(a).

The data revealed that, the emulsion stability decreases as the number of propylene oxide units increased, and it is a moderate emulsifying agents.

Generally, the surfactant solubility in the oil phase decreases by increasing the hydrophilic part (head), which weaken the emulsion stability [55] [56].

\subsection{CMC Measurements}

CMC is an important feature of a surfactant which measures the efficiency of the prepared surfactants. Before reaching the CMC the surface tension is dramatically changed with the surfactant concentration, and after reaching the CMC, the surface tension remains relatively constant or changes with a lower slope. Surfactants with low CMC values exhibit excellent emulsifying, wetting, solubilizing and detergency properties. As outlined in Table 3(a), Table 3(b), the measured surface tension, $\mathrm{CMC}$ values and the surface tension at the critical micelle concentration $\left(\gamma_{\text {СMC }}\right)$ of compounds $2_{(a-c)}-9_{(a-c)}$ increased with the increasing number of moles of propylene oxide incorporated in the structures, which in agreement with the reported results [57].

\subsection{Effectiveness ( $\pi_{\text {смс })}$}

The ability of a surfactant to induce the maximum reduce in the surface tension is a measure of the effectiveness of a surfactant $\left(\pi_{\mathrm{CMC}}\right)$. Since the CMC represents the minimum concentration of the surfactant needed for the maximum reduction in surface tension, thus, the effectiveness $\left(\pi_{\mathrm{CMC}}\right)$.

Can be measured from the decrease in the surface tension of the water $\left(\gamma_{0}\right)$, which is induced by this surfactant at CMC. Table 3(b) showed Logically decreasing in the effectiveness of the prepared surfactants $s$ as $\left(\gamma_{\mathrm{CMC}}\right)$ increased.

\subsection{Efficiency $\left(\mathrm{PC}_{20}\right)$}

In aqueous media, surface active compounds act by lowering the surface tension in between water molecules, so, the surfactant performance can be measured in terms of its adsorption efficiency which is known as surfactant adsorption efficiency and defined as the surfactant concentration required to produce a 20 
$\mathrm{mN} / \mathrm{m}$ reduction in surface tension and denotes as $\mathrm{PC}_{20}$ and can be calculated by Equation (2).

Increasing $\mathrm{PC}_{20}$, increase the adsorption of surfactant at the interface and efficiently the surface tension reduced. Accordingly, the synthesized surfactant $\mathrm{PC}_{20}$ values are found to be decreased by increasing the number of moles of propylene oxide (Table 3(a), Table 3(b)).

\subsection{Maximum Surface Excess $\Gamma_{\max }$}

The excess of surfactant per unit area of surface is known as surface excess concentration which express the extent of the surfactant adsorption at the surface of the liquid. Gibbs equation, Equation (3) express the relation between surface tension and Surface excess concentration $\left(\Gamma_{\max }\right)$ and to the maximum surface concentration CMC, and efficiency [58].

$$
\pi_{\mathrm{CMC}}=20+2.303 n R T \Gamma_{\text {max }} \log \left[\frac{C_{\mathrm{CMC}}}{C_{\pi}-20}\right]
$$

The obtained data from applying Equation (3) are listed in (Table 3(b)). It showed that by increasing the number of propylene oxide units, the maximum surface excess increased and in range of 0.79 and $2.57 \mathrm{~mol} / \mathrm{cm}^{2}$.

\subsection{Minimum Surface Area $\left(A_{\min }\right)$}

The area per surfactant molecule $A_{\min }$ at the interface air/water at the saturated surface gives us information about the packing degree and the adsorbed surfactant orientation. (Table 3(b)) represent the calculated average areas $A_{\min }$ which exhibit a significant decrease in $A_{\text {min }}$.

Values as the number of propylene oxide units increased in a significant decrease in $A_{\text {min }}$. This indicates a high packing order upon increasing number of moles of propylene oxide (n).

\subsection{Hydrolysis Resistance}

Because of tremendous uses of surfactants in manufacture of detergents, the surfactant stability towards acid/base hydrolysis is an important factor in its utilization. The resistance of the synthesized nonionic surfactants towards acidic and alkaline hydrolysis was tested and the data obtained presented in (Table 4).

The data showed that, in acidic medium, compounds $1_{(\mathrm{a}-\mathrm{c})}$ to $9_{(\mathrm{a}-\mathrm{c})}$ show high stability when boiled for $30 \mathrm{~min}$, but they are less stable upon boiling for $60 \mathrm{~min}$. On the other hand, in alkaline medium, they affected slightly even after boiling for $60 \mathrm{~min}$. thus, the synthesized nonionic surfactants would be safe to be used in detergents manufacture.

\subsection{Biodegradability}

Biodegradation is the destruction a chemical by metabolic activity of microorganisms. Surfactants must be susceptible to biodegradation test in order to examine their safety to environment. The biodegradation of the synthesized sur- 
factants was evaluated by the conventional River Die-Away test [59] and the data listed in (Table 5).

All the synthesized nonionic surfactants seem to degrade easily as the results showed. About $40 \%$ - 50\% of the surfactants was biodegradable within the first day of the test, and died away through 7 days. Consequently, these surfactants are safe for human beings as well as the environment. In general, the biodegradation of the surfactants decreases by increasing the number of propylene oxide units incorporated in the structure.

Table 4. Resistance of the synthesized surfactants towards acidic and alkaline hydrolysis.

\begin{tabular}{|c|c|c|c|c|c|c|c|}
\hline \multirow{3}{*}{ Compound } & \multirow{3}{*}{$\begin{array}{l}\text { Surface tension } \\
(\mathrm{mN} / \mathrm{m}) 0.1 \mathrm{wt} \%\end{array}$} & \multicolumn{6}{|c|}{$\begin{array}{l}\text { Surface tension (mN/m) } 0.1 \% \text { surfactant } \\
\text { (stability to hydrolysis) }\end{array}$} \\
\hline & & \multirow{2}{*}{$\begin{array}{l}\mathrm{H}_{2} \mathrm{SO}_{4}(5 \%) \\
25^{\circ} \mathrm{C}\end{array}$} & \multicolumn{2}{|c|}{$\begin{array}{l}\text { After boiling } \\
(5 \%) \mathrm{H}_{2} \mathrm{SO}_{4}\end{array}$} & \multirow{2}{*}{$\begin{array}{c}\mathrm{NaOH} \\
\text { (1\%) } 25^{\circ} \mathrm{C}\end{array}$} & \multicolumn{2}{|c|}{$\begin{array}{l}\text { After boiling } \\
\mathrm{NaOH}(1 \%)\end{array}$} \\
\hline & & & $30 \mathrm{~min}$ & $60 \mathrm{~min}$ & & $30 \mathrm{~min}$ & $60 \mathrm{~min}$ \\
\hline $2 a$ & 32 & 35 & 36 & 38 & 34 & 35 & 35 \\
\hline $2 \mathrm{~b}$ & 33 & 37 & 37 & 38 & 37 & 37 & 37 \\
\hline $2 c$ & 35 & 36 & 39 & 42 & 38 & 39 & 40 \\
\hline $3 a$ & 30 & 30 & 31 & 34 & 30 & 30 & 30 \\
\hline $3 b$ & 32 & 31 & 33 & 34 & 30 & 30 & 31 \\
\hline $3 c$ & 33 & 34 & 34 & 36 & 33 & 33 & 34 \\
\hline $4 a$ & 31 & 32 & 33 & 34 & 31 & 31 & 31 \\
\hline $4 \mathrm{~b}$ & 32 & 35 & 36 & 36 & 33 & 34 & 34 \\
\hline $4 c$ & 35 & 37 & 38 & 40 & 37 & 37 & 38 \\
\hline $5 a$ & 30 & 33 & 33 & 36 & 32 & 32 & 33 \\
\hline $5 b$ & 32 & 34 & 34 & 35 & 32 & 33 & 33 \\
\hline $5 c$ & 34 & 36 & 36 & 38 & 34 & 35 & 35 \\
\hline $6 a$ & 30 & 35 & 35 & 37 & 34 & 34 & 35 \\
\hline $6 \mathrm{~b}$ & 32 & 36 & 37 & 40 & 37 & 37 & 37 \\
\hline $6 c$ & 36 & 37 & 39 & 41 & 36 & 38 & 39 \\
\hline $7 a$ & 33 & 38 & 39 & 43 & 37 & 38 & 38 \\
\hline $7 \mathrm{~b}$ & 31 & 35 & 34 & 44 & 37 & 39 & 39 \\
\hline $7 \mathrm{c}$ & 32 & 36 & 37 & 46 & 38 & 40 & 40 \\
\hline $8 a$ & 31 & 31 & 33 & 34 & 31 & 30 & 31 \\
\hline $8 \mathrm{~b}$ & 33 & 32 & 32 & 34 & 33 & 33 & 33 \\
\hline $8 \mathrm{c}$ & 36 & 33 & 34 & 37 & 34 & 35 & 35 \\
\hline $9 \mathrm{a}$ & 32 & 34 & 36 & 37 & 33 & 33 & 34 \\
\hline $9 b$ & 33 & 35 & 36 & 39 & 33 & 35 & 35 \\
\hline $9 c$ & 35 & 37 & 38 & 42 & 35 & 37 & 37 \\
\hline
\end{tabular}


Table 5. Biodegradability of the synthesized surfactants.

\begin{tabular}{|c|c|c|c|c|c|c|c|c|}
\hline Compound & No. of moles a & $1^{\text {st }}$ Day & $2^{\text {nd }}$ Day & $3^{\text {rd }}$ Day & $4^{\text {th }}$ Day & $5^{\text {th }}$ Day & $6^{\text {th }}$ Day & $7^{\text {th }}$ Day \\
\hline & 3 & 51 & 62 & 77 & 84 & 94 & - & - \\
\hline \multirow[t]{3}{*}{$2(a-c)$} & 5 & 46 & 54 & 68 & 71 & 84 & 91 & - \\
\hline & 7 & 41 & 52 & 65 & 67 & 81 & 88 & - \\
\hline & 3 & 49 & 58 & 67 & 75 & 82 & 87 & - \\
\hline \multirow[t]{3}{*}{$3(a-c)$} & 5 & 46 & 51 & 58 & 69 & 76 & 84 & - \\
\hline & 7 & 41 & 52 & 56 & 67 & 72 & 83 & 91 \\
\hline & 3 & 53 & 69 & 74 & 83 & 97 & - & - \\
\hline \multirow[t]{3}{*}{$4(a-c)$} & 5 & 49 & 62 & 67 & 78 & 85 & 92 & - \\
\hline & 7 & 46 & 55 & 57 & 66 & 76 & 89 & - \\
\hline & 3 & 53 & 66 & 75 & 85 & 95 & - & - \\
\hline \multirow[t]{3}{*}{$5(a-c)$} & 5 & 48 & 60 & 68 & 78 & 91 & - & - \\
\hline & 7 & 45 & 50 & 62 & 74 & 83 & 93 & - \\
\hline & 3 & 56 & 68 & 79 & 86 & 96 & - & - \\
\hline \multirow[t]{3}{*}{$6(a-c)$} & 5 & 53 & 62 & 69 & 85 & 94 & - & - \\
\hline & 7 & 51 & 60 & 66 & 84 & 93 & - & - \\
\hline & 3 & 50 & 60 & 77 & 84 & 94 & - & - \\
\hline \multirow[t]{3}{*}{$7(a-c)$} & 5 & 46 & 54 & 68 & 71 & 84 & 95 & - \\
\hline & 7 & 41 & 52 & 65 & 67 & 80 & 93 & - \\
\hline & 3 & 51 & 62 & 78 & 86 & 93 & - & - \\
\hline \multirow[t]{3}{*}{$8(a-c)$} & 5 & 46 & 55 & 69 & 73 & 85 & 91 & - \\
\hline & 7 & 42 & 54 & 66 & 69 & 80 & 90 & - \\
\hline & 3 & 54 & 61 & 73 & 81 & 90 & - & - \\
\hline \multirow[t]{2}{*}{$9(a-c)$} & 5 & 51 & 60 & 77 & 84 & 91 & - & - \\
\hline & 7 & 47 & 58 & 66 & 78 & 85 & 92 & - \\
\hline
\end{tabular}

${ }^{a}$ Number of propylene oxide units

\section{Conclusions}

New thiadiazole derivatives (2 - 9) have been successfully synthesized in good yield. The synthesized compounds (2 - 9) exhibited high activity toward strains of $\mathrm{G}^{-}, \mathrm{G}^{+}$bacteria, while compound (7) showed good antifungal activity. The new nonionic surfactants bearing heterocyclic moieties were synthesized efficiently by incorporation of different moles of propylene oxide.

All the synthesized nonionic surfactants revealed good surface active properties which affected by the hydrophilic part. The lower the number of propylene oxide units, the surface and interfacial synthesized nonionic surfactants tension of the synthesized surfactants is markedly changed by the change of the hydrophilic part. Consequently, the CMC and $\Gamma_{\max }$, effectiveness $\left(\pi_{\mathrm{CMC}}\right)$, emulsion sta- 
bility, efficiency $\left(\mathrm{PC}_{20}\right)$ and minimum surface area $\left(A_{\min }\right)$ were changed.

Additionally, the new synthesized surfactants exhibit good fastness towards alkaline/acidic media and they are susceptible to degrade within one week. In conclusion, the new synthesized thiadiazole derivatives surfactants are safe for both human beings and the environment. So, it can be recommended as wetting, moderate emulsifiers as well as cosmetics, textiles and dyes manufacture.

\section{References}

[1] Prior, R.L., Wu, X. and Schaichs, K.J. (2005) Standardized Methods for the Determination of Antioxidant Capacity and Phenolics in Foods and Dietary Supplements. Journal of Agricultural and Food Chemistry, 53, 4290-4302.

https://doi.org/10.1021/jf0502698

[2] El-Nezhawy, A.O.H., Ramla, M.M., Khalifa, N.M. and Abdulla, M.M. (2009) Synthesis and Antioxidant Activity of Some Thiazolidin-4-One Derivatives. Monatshefte für Chemie, 140, 531-539. https://doi.org/10.1007/s00706-008-0085-3

[3] Grasso, S., Chimirri, A., Monforte, P. and Fenech, G. (1984) Compounds with Presumed Antitumor Activity. II. 2-Substituted 3-(2-thiazolyl)- and 3-[2-(1,3,4thiadiazolyl)]-4-thiazolidinones. Farmaco, 39, 505-513. https://doi.org/10.1002/chin.198449188

[4] Grasso, S., Chimirri, A., Monforte, P., Fenech, G., Zappala, M. and Monforte, A.M. (1988) Compounds with Potential Antitumor Activity. VI. 2-Alkyl-3-[2(1,3,4-thiadiazolyl)]-4-thiazolidinones Farmaco, 43, 851-856.

[5] Groenikaki, A.A., Lagunin, A.A., Hadjipavlou-Litina, D.I., Eleftheriou, P.T., Filimonov, D.A., Poroikov, V.V., Alam, I. and Saxena, A.K. (2008) Computer-Aided Discovery of Anti-Inflammatory Thiazolidinones with Dual Cyclooxygenase/Lipoxygenase Inhibition. Journal of Medicinal Chemistry, 51, 1601-1609. https://doi.org/10.1021/jm701496h

[6] Bhati, S.K. and Kumar, A. (2008) Synthesis of New Substituted Azetidinoyl and Thiazolidinoyl-1,3,4-thiadiazino (6,5-b) Indoles as Promising Anti-Inflammatory Agents. European Journal of Medicinal Chemistry, 43, 2323-2330. https://doi.org/10.1016/j.ejmech.2007.10.012

[7] Dwivedi, V. and Aggarwal, R.K. (1992) Synthesis and Fungicidal Activities of Some 2-furly-3-[(5-aryloxymethyl)-1,3,4-thiadiazol-2-yl]thiazolidin-4-ones. Asian Journal of Chemistry, 4, 780-784.

[8] Gaur, V.B., Shah, V.H. and Parikh, A.R. (1990) Studies on 4-Thiazolidinones. Preparation and Antimicrobial Activity of 2-aryl-3-(5-o-hydroxyphenyl/p-nitrophenyl1,3,4-thiadiazol-2-yl)-5-carboxymethyl-4-thiazolidinones. Acta Ciencia Indica. Chemistry, 16C, 437-444.

[9] Rawal, R.K., Tripathi, R., Katti, S.B., Pannecouque, C. and Clercq, E.D. (2007) Design, Synthesis, and Evaluation of 2-aryl-3-heteroaryl-1,3-thiazolidin-4-ones as Anti-HIV Agents. Bioorganic \& Medicinal Chemistry, 15, 1725-1731. https://doi.org/10.1016/j.bmc.2006.12.003

[10] Rawal, R.K., Tripathi, R., Katti, S.B., Pannecouque, C. and Clercq, E.D. (2008) Design and Synthesis of 2-(2,6-dibromophenyl)-3-heteroaryl-1,3-thiazolidin-4-ones as Anti-HIV Agents. European Journal of Medicinal Chemistry, 43, 2800-2806. https://doi.org/10.1016/j.ejmech.2007.12.015

[11] Rawal, R.K., Katti, S.B., Kaushik-Basu, N., Arora, P. and Pan, Z. (2008) Non-Nuc- leoside Inhibitors of the Hepatitis C Virus NS5B RNA-Dependent RNA Polymerase: 
2-Aryl-3-heteroaryl-1,3-thiazolidin-4-one Derivatives. Bioorganic \& Medicinal Chemistry Letters, 18, 6110-6114. https://doi.org/10.1016/j.bmcl.2008.10.023

[12] Chimirri, A., Grasso, S., Monforte, A.M., Zappala, M., De Sarro A. and De Sarro, G.B. (1991) Synthesis and Anticonvulsant Properties of 3-(1,3,4-thiadiazol-2-yl)thiazolidin4-ones. Farmaco, 46, 935-943.

[13] Gad El-Karim, I.A., Amine, M.S., Mahmoud, A.A. and Gouda, A.S. (2014) Fatty Acids in Heterocyclic Synthesis. Part XIV: Synthesis of Surface Active Agents from Some Novel Class of Oxadiazole, Thiadiazole and Triazole Derivatives Having Microbiological Activities. Journal of Surfactants and Detergents, 17, 509-523. https://doi.org/10.1007/s11743-013-1530-9

[14] Amine, M.S., Aly, A.A. and El-Sayed, R. (2006) Synthesis and Surface Active Properties of Condensed and Non-Condensed Quinazoline Derivatives of Industrial Application. Indian Journal of Chemistry, 45B, 1020-1027.

[15] Amine, M.S., Eissa, A.M.F., Elsawy, A.A., Shaaban, A.F., El sayed, R. and Grasas, A. (2004) New Heterocycles Having a Double Characters as Antimicrobial and Surface Active Agents. Part 1: Nonionic Compounds from Fatty Acid Isothiocyanate. Indian Journal Chemistry, 44B, 1724-1730.

[16] Amine, M.S., Mahmoud, A.A., Badr, S.K. and Gouda, A.S. (2011) Fatty Acids in Heterocyclic Synthesis. Part XIII: 2-chloro-5-heptadecyl[1,3,4]thiadiazole as a Building Block for Synthesis of S-triazolo[2,4-b]thiadiazole, benzimidazo[2, l-b]thiadiazole, thiadiazolo[2,3-b]quinazolin-5-one as Well as Thiadiazol-2-yl (piperidine, Pyridazine and/or Phthalazine). Olaj, Szappan, Kozmetika, 60, 51-57.

[17] Amine, M.S., Mahmoud, A.A., Badr, S.K. and Gouda, A.S. (2013) Fatty Acids in Heterocyclic Synthesis. Part XI: Facile and Convenient Routes to Synthesize Ecofriendly Polyfunctionalized Thiadiazoles, Triazole, Thiadiazolo [3,2-a] pyrimidines and Imidazo[2,1-b]thiadiazole for Pharmaceutical and Industrial Purposes. Egyptian Journal of Chemistry, 56, 379-401.

[18] Amine, M.S., Mahmoud, A.A., Badr, S.K. and Gouda, A.S. (2012) Fatty Acids in Heterocyclic Synthesis Part XII: Synthesis of Surfactants from Pyrazole, Isoxazole, Pyrimidine and Triazine, Incorporating the 1,3,4-thiadiazole Moiety Having Dyeing and Antimicrobial Activities. Journal of Surfactants and Detergents, 15, 179-190. https://doi.org/10.1007/s11743-011-1301-4

[19] Amine, M.S., Ahmed, M.H.M., Hebash, K.A. and El-Sheikh, A.A. (2007) New Heterocycles Having a Double Character as Antimicrobial and Surface Active Agents. Part 6, Novel Thiadiazole from Stearic Acid. Olaj, Szappan, Kozmetika, 56, 57-61.

[20] Bauer, A.W., Kirby, W.M., Sherris, C. and Turck, M. (1966) Antibiotic Susceptibility Testing by a Standardized Single Disk Method. American Journal of Clinical Pathology, 45, 493-496.

[21] Liebowitz, L.D., Ashbee, H.R., Evans, E.G.V., Chong, Y., Mallatova, N., Zaidi, M. and Gibbs, D. (2001) A Two Year Global Evaluation of the Susceptibility of Candida Species to Fluconazole by Disk Diffusion. Diagnostic Microbiology and Infectious Disease, 4, 27-33. https://doi.org/10.1016/S0732-8893(01)00243-7

[22] Matar, M.J., Ostrosky-Zeichner, L., Paetznick, V.L, Rodriguez, J.R., Chen, E. and Rex, J.H. (2003) Corelation between E-Test, Disk Diffusion, and Microdilution Methods for Antifungal Susceptibility Testing of Fluconazole and Voriconzale. Antimicrobial Agents and Chemotherapy, 47, 1647-1651. https://doi.org/10.1128/AAC.47.5.1647-1651.2003

[23] National Committee for Clinical Laboratory Standards (1993) Performance Vol. 41, 1997. Antimicrobial Susceptibility of Flavobacteria. 
[24] Morgos, J., Sallay, P., Farkas, L. and Rusznak, I. (1983) A Novel Way for Ethoxylation with Basic Catalyst. Journal of the American Oil Chemists Society, 60, 1905-1907. https://doi.org/10.1007/BF02901549

[25] Ahmed, M.H.M., Sallay, P., Rusznak, I. and Farkas, L. (1996) Determination of the Average Ethoxylation Degree. Tenside Surfactants Detergents, 33, 410-411.

[26] Findlay, A. (1963) Practical Physical Chemistry. 6th Edition, Longmans, London, 1040-1069.

[27] Weil, J.K., Stirton, A.J. and Nunez-Ponzoa, M.V. (1966) Ether Alcohol Sulfates. The Effect of Oxypropylation and Oxybutylation on Surface Active Properties. Journal of the American Oil Chemists Society, 43, 603-609. https://doi.org/10.1007/BF02640796

[28] ASTM D1331-01 (2001) Standard Test Method for Surface and Interfacial Tension of Solutions of Surface Active Agents.

[29] Durham, K. (1961) Properties of Detergent Solutions-Amphipathy and Adsorption, Vol. 1. Surf Activity Deterg. MacMillan \& Co. Ltd., London, 1-28.

[30] Draves, C.Z. and Clarkson, R. (1931) A New Method for the Evaluation of Wetting Agents. American Dyestuff Reporter, 20, 201.

[31] Ross, J. and Milles, G.D. (1941) Apparatus for Comparison of Foaming Properties of Soaps and Detergents. Oil Soap, 18, 99-102. https://doi.org/10.1007/BF02545418

[32] Scholnick, F. and Linfield, W.M. (1977) Lactose-Derived Surfactants (III): Fatty Esters of Oxyalkylated Lactitol. Journal of the American Oil Chemists Society, 54, 430-435. https://doi.org/10.1007/BF02671026

[33] Colwell, C.E. and Rixon, W.E. (1961) Consideration in the Use of Nonionic Surface-Active Agents. American Dyestuff Reporter, 50, 679-682.

[34] Lu, J.R., Lee, E.M., Thomas, R.K., Penfold, J. and Flitsch, S.L. (1993) Direct Determination by Neutron Reflection of the Structure of Triethylene Oxide Monododecyl Ether Layers at the Air/Water Interface. Langmuir, 9, 1352-1358. https://doi.org/10.1021/la00029a032

[35] Matsuoka, K. and Moroi, Y. (2003) Micellization of Fluorinated Amphiphiles. Current Opinion in Colloid \& Interface Science, 8, 227-234.

https://doi.org/10.1016/S1359-0294(03)00056-6

[36] Xu, Z., Li, P., Qi, W., Li, Z. and Lubo, C. (2006) Effect of Aromatic Ring in the Alkyl Chain on Surface Properties of Aryl Alkyl Surfactant Solution. Journal of Surfactants and Detergents, 9, 245-248. https://doi.org/10.1007/s11743-006-5004-1

[37] Karakashev, S.I., Nguyen, A.V. and Miller, J.D. (2008) Equilibrium Adsorption of Surfactants at the Gas-Liquid Interface. Advances in Polymer Science, 218, 25-55. https://doi.org/10.1007/12_2008_161

[38] Karakashev, S.I. and Manev, E.D. (2002) Effect of Interactions between the Adsorbed Species on the Properties of Single and Mixed Surfactant Monolayers at Air/Water Interfac. Journal of Colloid and Interface Science, 248, 477-486. https://doi.org/10.1006/jcis.2001.8206

[39] Falbe, J. (1986) Surfactants for Consumer. Chap. 4, Springer Verlag, Heidelberg.

[40] Amine, M.S., Ahmed, M.H.M., Hebash, K.A. and El-Sheikh, A.A. (2007) New Heterocycles Having a Double Character as Antimicrobial and Surface Active Agents. Part 6: Novel Thiadiazole from Stearic Acid. OLAJ, Szappan, Kozmetika, 56, 57-61.

[41] Tsuge, O., Oe, K. and Tashiro, M. (1977) Photolysis of 1,3,4-oxadiazoles in Alcohols. Chemistry Letters, 6, 1207-1210. https://doi.org/10.1246/cl.1977.1207 
[42] Hill, J. (1984) 4.23-1,3,4-Oxadiazoles. In: Katritzky, A.R. and Rees, C.W., Eds., Comprehensive Heterocyclic Chemistry I, Vol. 6, Pergamon, Oxford, 427. https://doi.org/10.1016/B978-008096519-2.00091-6

[43] Padmavathi, V., Thriveni, P., Sudhakar, R.G. and Deepti, D. (2008) Synthesis and Antimicrobial Activity of Novel Sulfone-Linked bis Heterocycles. European Journal of Medicinal Chemistry, 43, 917-924. https://doi.org/10.1016/j.ejmech.2007.06.011

[44] Kumar, H., Javad, S.A., Khan, A. and Amir, M. (2008) 1,3,4-Oxadiazole/Thiadiazole and 1,2,4-Triazole Derivatives of Biphenyl-4-yloxy Acetic Acid: Synthesis and Preliminary Evaluation of Biological Properties. European Journal of Medicinal Chemistry, 43, 2688-2698. https://doi.org/10.1016/j.ejmech.2008.01.039

[45] El-Emam, A.A., Al-Deeb, O.A., Al-Omara, M. and Lehmann, J. (2004) Synthesis, Antimicrobial, and Anti-HIV-1 Activity of Certain 5-(1-adamantyl)-2-substituted thio-1,3,4-oxadiazoles and 5-(1-adamantyl)-3-substituted Aminomethyl-1,3,4oxadiazoline-2-thiones. Bioorganic \& Medicinal Chemistry, 12, 5107-5113. https://doi.org/10.1016/j.bmc.2004.07.033

[46] Shaoyong, K., Fengyi, L., Wang, N., Yang, Q. and Qian, X. (2009) 1,3,4-Oxadiazoline Derivatives as Novel Potential Inhibitors Targeting Chitin Biosynthesis: Design, Synthesis and Biological Evaluation. Bioorganic \& Medicinal Chemistry, 19, 332-335. https://doi.org/10.1016/j.bmcl.2008.11.095

[47] Miller, P. and Westra, P. (1998) How Surfactants Work. Coop. Ex., Prod. Crop Ser. No. 564.

[48] Chlebicki, J. and Sokołowski, A. (1991) Adsorption of n Alkylthiooligooxypropylene Glycols at Aqueous Solution-Air Interface. Colloids and Surfaces, 56, 251-261. https://doi.org/10.1016/0166-6622(91)80125-8

[49] Chen, M.L., Wang, Z.W., Zhang, G.X., Gu, J., Cun, Z. and Tao, F.M. (2007) Studies on the Cloud Points of Nonionic Surfactants with QSPR. Chemical Research in Chinese Universities, 23, 715-719.

[50] Mitchell, D.J., Tiddy, G.J.T., Waring, L., Bostock, T. and McDonald, M.P. (1983) Phase Behaviour of Polyoxyethylene Surfactants with Water. Journal of the Chemical Society, Faraday Transactions, 79, 975-1000. https://doi.org/10.1039/f19837900975

[51] Schott, H.J. (1969) Hydrophile-Lipophile Balance and Cloud Points of Nonionic Surfactants. Journal of Pharmaceutical Sciences, 58, 1443-1449. https://doi.org/10.1002/jps.2600581203

[52] Ahmed, M.H.M. (2004) Preparation and Surface Active Properties of Novel Succinic Acid Based Surfactants. OLAJ Szappan Kozmetika, 53, 23-28.

[53] Eissa, A.M.F. and El-Sayed, R. (2007) Synthesis and Evaluation of Ahydroxy Fatty Acid-Derived Heterocyclic Compounds with Potential Industrial Interest. Grasas $y$ Aceites, 58, 20-28. https://doi.org/10.3989/gya.2007.v58.i1.4

[54] Kim, T.S., Kida, T., Nakatsuji, Y., Hirao, T. and Ikeda, J.I. (1996) Surface Active Properties of Novel Cationic Surfactants with Two Alkyl Chains and Two Ammonia Groups. Journal of the American Oil Chemists' Society, 73, 907-912. https://doi.org/10.1007/BF02517994

[55] El-Sukkary, M.M.A., Syed, N.A., Aiad, I. and El-Azab, W.I.M. (2008) Synthesis and Characterization of Some Alkyl Polyglycosides Surfactants. Journal of Surfactants and Detergents, 11, 129-137. https://doi.org/10.1007/s11743-008-1063-9

[56] Takeshi, H. (1970) Studies of Ester Containing Surfactant: Preparation and Properties of Sodium Sulfalkanoates. Bulletin of the Chemical Society, 43, 2236-2239. https://doi.org/10.1246/bcsj.43.2236 
[57] Rosen, M.J. (2004) Surfactants and Interfacial Phenomena. 3rd Edition, Wiley, New York. https://doi.org/10.1002/0471670561

[58] Eter, E.T., Richard, R.E. and David, A. (1974) Biodegradable Surfactants Derived from Corn Starch. Journal of the American Oil Chemists' Society, 51, 486-494. https://doi.org/10.1007/BF02635857

[59] Balson, T. and Felix, M.S.B. (1995) The Biodegradability of Non-Ionic Surfactants. Biodegradability of Surfactants. Springer, Berlin, 204-230.

https://doi.org/10.1007/978-94-011-1348-9_7 